\title{
Hydrologic Behavior of Two Engineered Barriers Following Extreme Wetting
}

I. Porro

September 2000

Idaho National Engineering and Environmental Laboratory Bechtel BWXT Idaho, LLC 


\section{Hydrologic Behavior of Two Engineered Barriers Following Extreme Wetting}

Indrek Porro

September 2000

Idaho National Engineering and Environmental Laboratory Applied Geosciences Department Idaho Falls, Idaho 83415

Prepared for the

U.S. Department of Energy

Assistant Secretary for Environmental Management

Under DOE Idaho Operations Office

Contract DE-AC07-99ID13727 


\begin{abstract}
Many engineered barriers are expected to function for hundreds of years or longer. Over the course of time, it is likely that some barriers will experience infiltration to the point of breakthrough. This study compares the recovery from breakthrough of two storage-evapotranspiration type engineered barriers.

Replicates of test plots comprising thick soil and capillary/biobarrier covers were wetted to breakthrough in 1997. Test plots were kept cleared of vegetation to maximize hydrologic stress during recovery. Following cessation of drainage resulting from the wetting irrigations, water storage levels in all plots were at elevated levels compared to pre-irrigation levels. As a result, infiltration of melting snow during the subsequent spring overloaded the storage capacity and produced drainage in all plots. Relatively rapid melting of accumulated snowfall produced the most significant infiltration events each year during the study. Capillary barriers yielded less total drainage than thick soil barriers. By limiting drainage, capillary barriers increased water storage in the upper portions of the test plots, which led to increased evaporation from the capillary barrier plots compared to thick soil plots. Increased evaporation in the capillary barrier plots allowed more water to infiltrate in the second season following the wetting tests without triggering drainage. All thick soil plots again yielded drainage in the second season. Within two years of intentionally induced breakthrough, evaporation alone (without transpiration) restored the capability of the capillary barrier covers to function as intended, although water storage in these covers remained at elevated levels.
\end{abstract}




\section{ACKNOWLEDGMENTS}

The author gratefully acknowledges project management support provided by Tom Honeycutt and Rajiv Bhatt, and Tim Kaser's efforts in maintaining the data acquisition system. 


\section{CONTENTS}

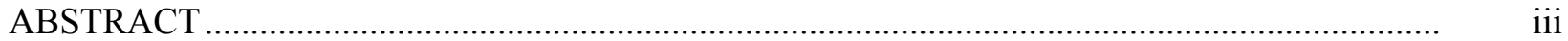

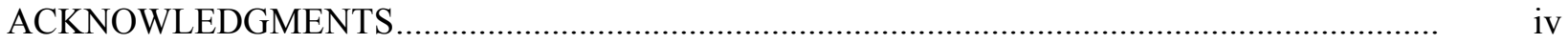

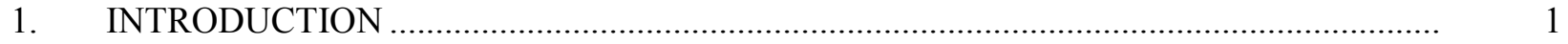

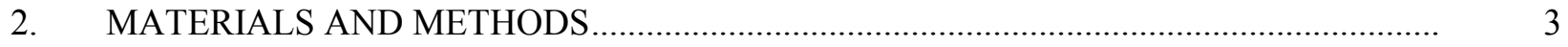

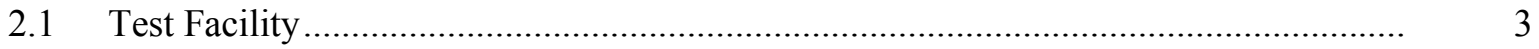

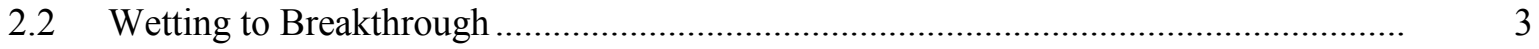

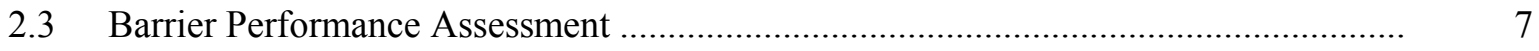

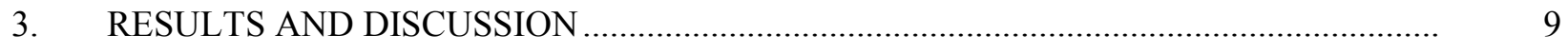

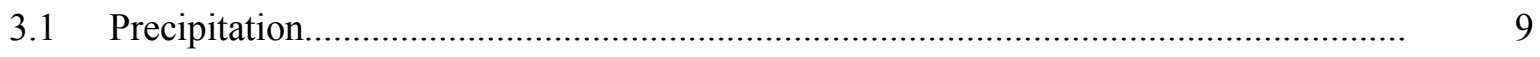

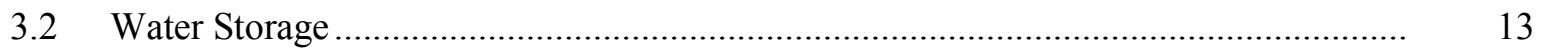

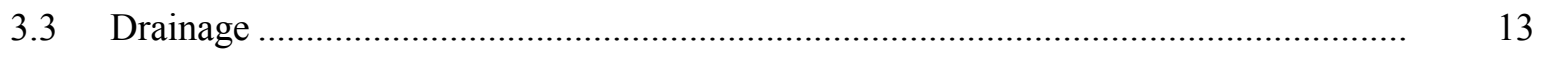

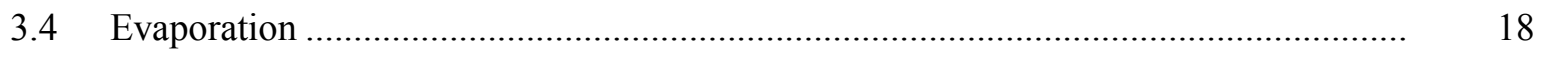

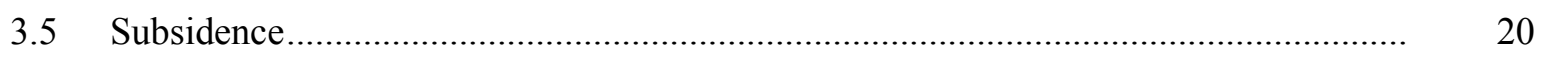

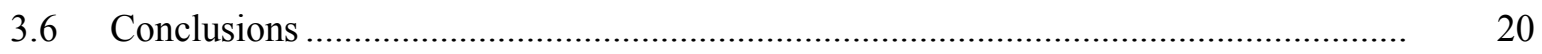

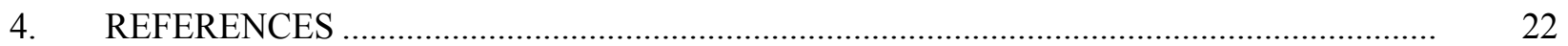

FIGURES

1. Schematic of the cover designs being tested: (top) thick soil, (bottom) thick soil with

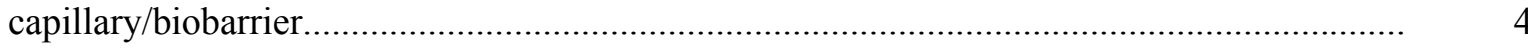

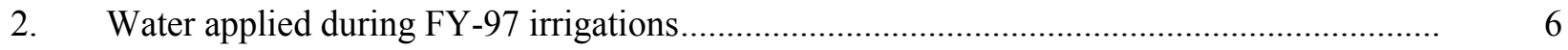

3. Cumulative precipitation during FY-97, FY-98, and FY-99 and long-term average cumulative

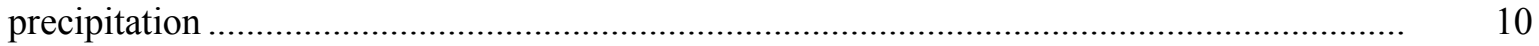

4. Depths of soil freezing during FY-97, FY-98, and FY-99 in a representative test plot........... 11

5. Snow depths at CFA and the test facility during FY-97, FY-98, and FY-99 and long-term average snow depth

6. Average TDR-measured water content profiles in B plots (a) and S plots (b) 


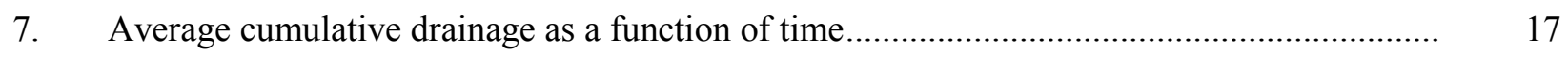

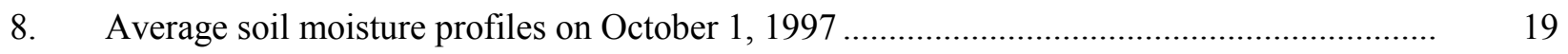

\section{TABLES}

1. Irrigation dates and amounts of water applied (FY-97) …................................................ 5

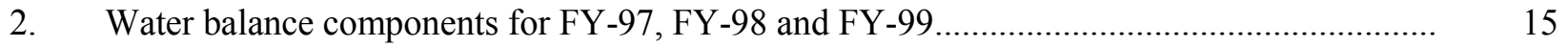

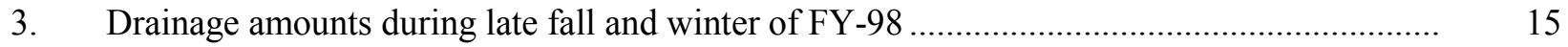

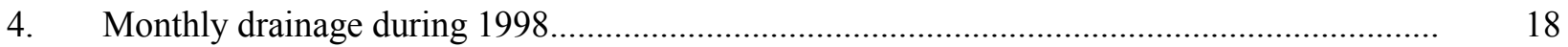




\section{Hydrologic Behavior of Two Engineered Barriers Following Extreme Wetting}

\section{INTRODUCTION}

Worker and public health and safety concerns associated with remediation of contaminated sites, the lack of proven remediation technologies, and economic considerations have led to the consideration of containment and isolation as viable alternatives to managing buried wastes and contaminated soils. The most serious problems encountered in shallow land burial of wastes are related to water management (Jacobs et al., 1980; Fisher, 1986; Nativ, 1991). The movement of water through buried wastes is recognized as a major mechanism for transporting wastes beyond their original burial boundaries. As a result, a major objective of many containment and isolation projects is to minimize the movement of water into the waste (O'Donnell et al., 1994; Daniel and Gross, 1995). Engineered surface barriers are often used to satisfy this objective.

Most engineered surface covers are made up of several layers which can be categorized as follows: (1) surface layer, (2) protection layer, (3) drainage layer, (4) barrier layer, and (5) gas collection or foundation layer (Daniel, 1994). Design of these covers generally follows the technical guidance for hazardous waste landfills issued by the U.S. Environmental Protection Agency (USEPA, 1989). However, not all layers are needed in every barrier. The environment in which the engineered barrier will be employed and the performance objectives of the barrier will often determine the specific design required. Additionally, not all layers function effectively over the long term. The traditional surface barriers incorporate a compacted soil layer designed to restrict water movement by virtue of its low permeability. There is increasing evidence that the permeability of these layers increases over time (particularly in arid environments) due to a variety of factors (e.g., desiccation cracking, freeze-thaw cycles, erosion, subsidence, root and animal intrusion, and initial flaws in construction) (Suter et al, 1993; Daniel, 1994; Melchior et al., 1994; Omidi et al., 1996). The limitations of currently required designs are driving the development of regulatory guidance that will allow the evaluation and use of new alternative materials and designs (Skahn, 1997).

Surface covers that do not use compacted soil layers and/or other impermeable materials to limit water flow have also been proposed. Anderson et al. (1993) describe a water storage-evapotranspiration cover for use in semiarid regions where potential evapotranspiration greatly exceeds precipitation. Their cover consists of a layer of soil sufficiently thick to store precipitation that falls while plants are dormant. Silt loam soils, in particular, have been shown to have superior water storage characteristics compared to soils of other textures (Petersen et al., 1995). Transpiration by plants established on the soil surface is used to recycle the stored water back into the atmosphere during the growing season, thereby preventing its movement downward into and through the waste. The water storage-evapotranspiration type covers are attractive in that mechanisms that increase the hydraulic conductivity of compacted soil covers and thereby significantly compromise their integrity may have little effect on the integrity of these covers because these covers do not rely on low hydraulic conductivity to function effectively. Including a capillary barrier below the water storage zone can provide additional protection against downward water flow. Capillary barriers refer to the interface between an upper fine-textured soil and a lower coarsetextured material. Under unsaturated conditions, water in the small pores of the fine-textured soil is held at high tensions and will not flow into the large pores of the coarse textured soil where the water tension is low. In order for water to flow out of the soil and into the coarse textured material it must be at sufficiently low tension. Tension decreases as the soil approaches saturation. Once breakthrough occurs, water will drain into the coarse material at a rate controlled largely by the hydraulic conductivity of the overlying soil. The restriction of water movement by a coarse layer in a soil has been recognized for a 
long time (Alway and McDole, 1917; Nelson and Baver, 1941; Robins, 1959; Eagleman and Jamison, 1961; Miller and Bunger, 1963). More recently, the flow-restrictive properties of capillary barriers are being exploited in designs of engineered surface barriers. Capillary barriers as components of engineered surface covers are the focus of several studies (Nyhan et al., 1990; Gee et al., 1993; Benson et al., 1994; Limbach et al., 1994; Dwyer, 1997; Ward and Gee, 1997; Warren et al. 1997; Khire et al., 1999). These studies notwithstanding, field data that are needed to properly evaluate capillary barrier performance and establish regulatory acceptance are limited (Daniel and Gross, 1995).

Two storage-evapotranspiration type surface covers are undergoing field tests at the Idaho National Engineering and Environmental Laboratory (Bhatt and Porro, 1998). One cover design consists of a thick soil (silt loam) layer with a plant cover. The other design incorporates a capillary/biobarrier within the thick soil (silt loam) layer. The cover(s) chosen for use at this site will be expected to function for hundreds, if not thousands, of years. Over the course of time, it is likely that the cover will be subjected to an extreme rainfall or flooding event that wets the cover to the point of breakthrough. In a worst case scenario, this could happen when the cover is devoid of vegetation, e.g. in the aftermath of a fire. It is of interest to know how these covers recover from such a condition.

Few studies have focused on this aspect of cover behavior. Campbell et al. (1990), working at the Hanford Site in Washington state, observed continuous drainage from two capillary barrier lysimeters for a year following intentional wetting to breakthrough. The lysimeters were covered with plastic during drainage. A second wetting, still under plastic cover, resulted in a "very slow rate" of drainage for another year. The lysimeters were then uncovered and exposed to ambient conditions. Gee et al. (1993) reported the total annual drainage for the next three years as 0,0 , and $2 \mathrm{~cm}$, respectively. Drainage during the last year was attributed to record snowfall. Stormont and Anderson (1999) conducted infiltration tests in the laboratory on soil columns of sand over gravel. They repeatedly wetted the columns to breakthrough. After each infiltration was terminated, columns were allowed to recover under laboratory conditions until the suction head near the interface increased above the breakthrough head of the gravel to restore the barrier. The breakthrough head did not change substantially after eight cycles of breakthrough and recovery.

Other studies, while not intentionally wetting test plots to breakthrough, have provided the opportunity to observe recovery as a result of exposure to natural conditions. Warren et al. (1997) reported the results from 45 months of field-testing various covers, including two capillary barrier covers and one soil-only cover, in northern Utah. Breakthrough drainage occurred during each year of the study in response to natural precipitation. Over $90 \%$ of all drainage occurred during the months of February through May. This was associated mostly with snowmelt and rain events in late winter and early spring months. Drainage occurred each year despite the fact that annual precipitation totals and snowfall amounts were at or below long-term averages during much of the study, and despite the fact that the covers were vegetated and sloped to enhance evapotranspiration and runoff. Although the capillary barrier covers allowed less drainage than the soil-only cover, annual total amounts were not significantly different. Nyhan et al. (1990) reported the results from a 3-year field study at Los Alamos, NM that compared the water balance of a capillary barrier to a conventional (crushed tuff backfill) cover. All breakthroughs occurred as a result of snowmelt. Breakthrough in the conventional plot occurred in the first and third winters of the study and lasted about a week and from December through April, respectively. Breakthrough in the capillary barrier plot occurred only after the third winter and lasted from early March through April. Breakthrough did not occur in either type of cover following the intervening winter despite a maximum record spring precipitation. All of the test plots were vegetated in this study and the capillary barrier was sloped at 5\% to enhance its diversion capacity.

The objective of this study is to compare the recovery from breakthrough of two types of surface covers under natural weather conditions. Runoff and evapotranspiration were eliminated to maximize the hydrologic stress on the covers during recovery. 


\section{MATERIALS AND METHODS}

\subsection{Test Facility}

This study is being conducted on the cold desert rangeland of the upper Snake River Plain in southeastern Idaho. The test facility is a concrete structure consisting of five cells (plots) on either side of an enclosed access trench. Each cell has four walls and a floor and measures $3.05 \mathrm{~m}$ wide by $3.05 \mathrm{~m}$ long by $3.05 \mathrm{~m}$ deep. The top of each cell is open to the atmosphere. Because of shallow soil at this location, soil is backfilled up around the facility so that cell tops are slightly above grade level. Each cell has two floor drains that empty into separate sumps in the access trench. One drain drains a 0.10-m wide trough that runs around the bottom perimeter of the cell. The other drain drains the remaining central portion of the cell. Each drained area is sloped toward its drain.

The access trench is approximately $26.2 \mathrm{~m}$ long by $3.0 \mathrm{~m}$ wide by $3.8 \mathrm{~m}$ deep and serves primarily as a protected area for housing the data acquisition system and those instruments (e.g. tensiometers) that penetrate the cell walls. A separate room at the south end of the access trench houses the data acquisition computer and serves as an office area. The access trench is supplied with $115-\mathrm{V}$ electrical service and a telephone line allowing remote access to real time and stored data. A heat pump mounted on the south end of the roof of the access trench minimizes temperature variations and prevents freezing within the access trench.

Figure 1 illustrates the two engineered barrier designs being tested. One cover design consists of a uniform layer of silt loam soil. This soil is covered with a 0.15 -m thick layer of mixed silt loam soil (75\% by volume) and gravel ( $25 \%$ by volume) designed to increase the cover's resistance to wind erosion. The other cover design consists of a similar soil-gravel surface layer underlain by $1.45 \mathrm{~m}$ of silt loam soil. Beneath this soil is a $0.15-\mathrm{m}$ thick layer of gravel and a $0.76-\mathrm{m}$ layer of cobbles. A sharp interface between the gravel and the overlying soil is maintained by a high conductivity geotextile. The interface forms a capillary barrier that impedes downward water flow during unsaturated conditions. The cobble layer is intended to minimize biointrusion beyond this depth. A second layer of silt loam soil underlies the cobble layer. The silt loam soil in all test plots comprises $22 \%$ sand, $53 \%$ silt, and $25 \%$ clay, with a porosity of 47.3. Specific properties of the pea-size gravel and softball-size cobbles were not determined. Both types of covers are designed to exploit the transpiration capabilities of plants to extract water that infiltrates into the covers. However, all test plots were maintained devoid of vegetation during the testing period described in this article. The absence of vegetation allows evaluation of the behavior of the barriers under the most extreme hydrologic conditions that are likely to occur. Four replicates of each design were built. The thick soil barrier design test plots are labeled S1 to S4. The capillary/biobarrier design test plots are labeled B1 to B4. Two additional test plots (labeled D5 and I5) were built with the thick soil barrier design for supplemental soil sampling and hydraulic property testing purposes.

\subsection{Wetting to Breakthrough}

All test plots were intentionally wetted to breakthrough in FY-97 (1 Oct. 1996 to 30 Sep. 1997). Water was applied to each plot using applicators comprising a parallel array of soaker hoses attached to PVC pipe manifolds. A control system was devised to allow simultaneous, independent operation of the applicators. Water was delivered from a 1,200-gallon tank to the applicators by a pump controlled from a datalogger located in the access trench. Rate of flow was established using pulses of water produced by energizing the pump for specified lengths of time. The timing and length of energization could be varied in order to achieve the average flow rate desired. The target rate of application for the irrigations was $16.4 \mathrm{~cm} /$ day, based on an estimate of the soil's saturated hydraulic conductivity (Magnuson, 1993). 


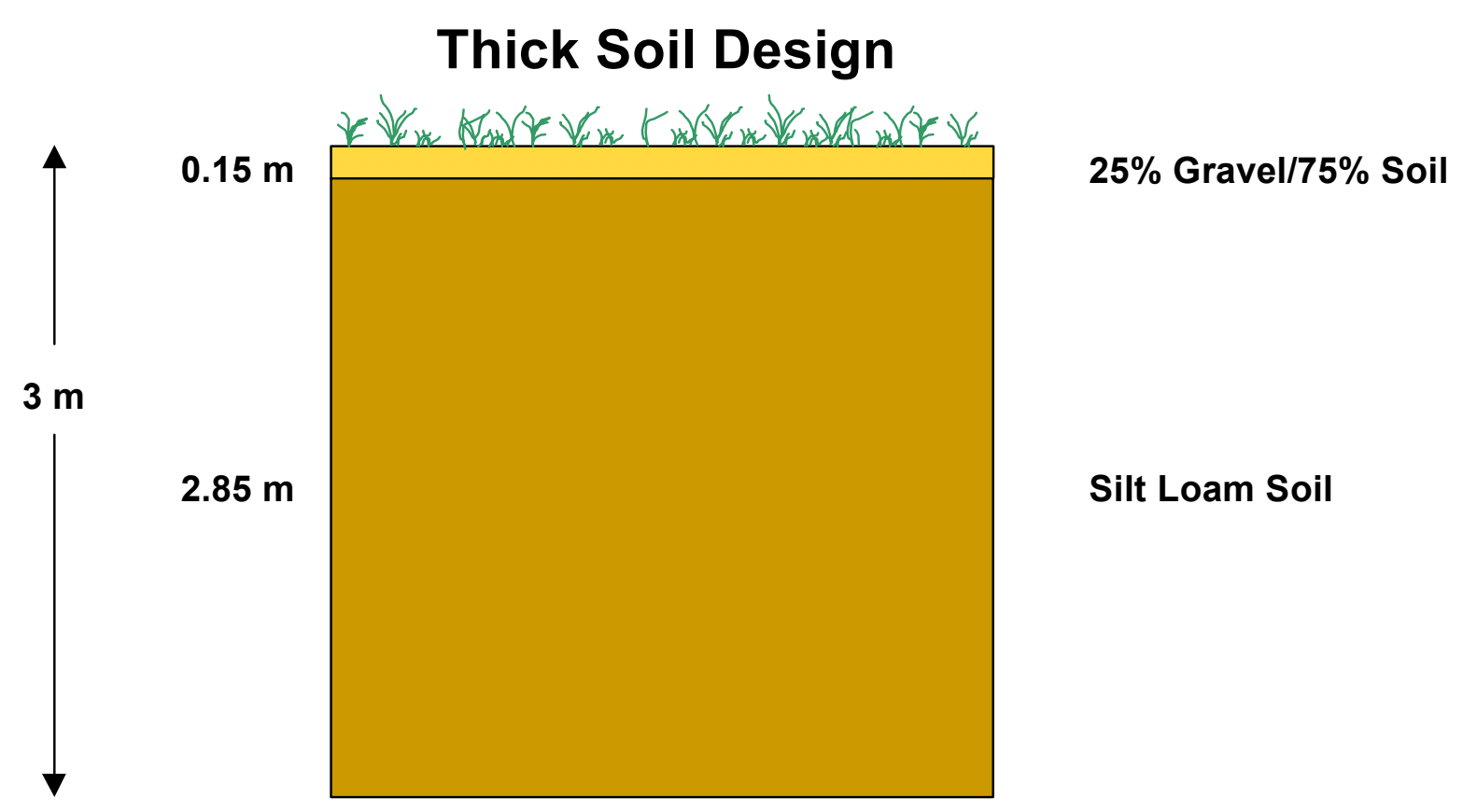

\section{Capillary/Biobarrier Design}

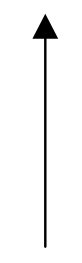

$0.15 \mathrm{~m}$

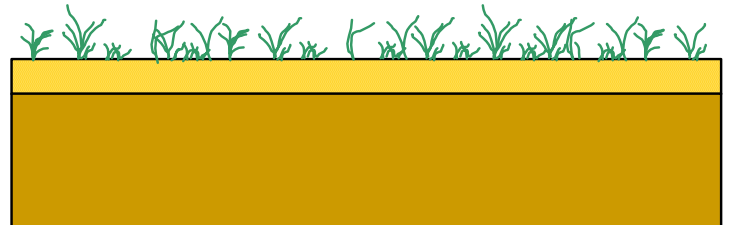

$3 \mathrm{~m}$

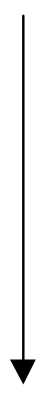

$0.15 \mathrm{~m}$

$0.76 \mathrm{~m}$

$0.49 \mathrm{~m}$

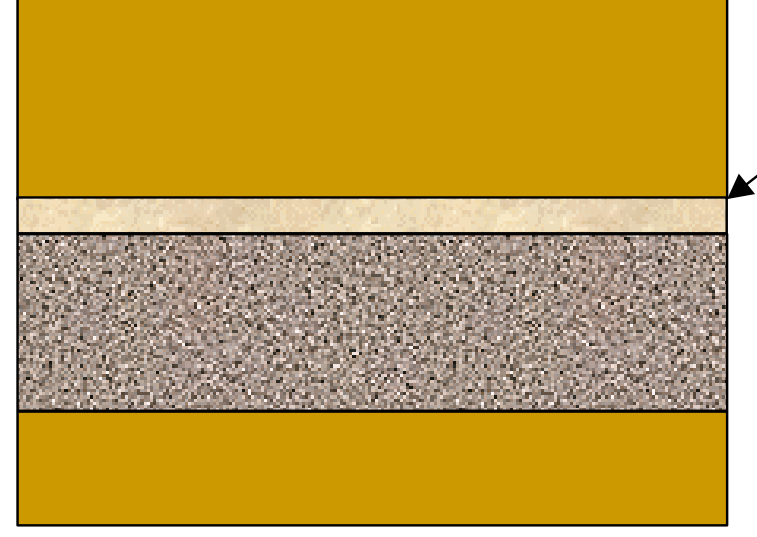

Silt Loam Soil

Geotextile Fabric

Gravel

Cobbles

Silt Loam Soil

Figure 1. Schematic of the cover designs being tested: (top) thick soil, (bottom) thick soil with capillary/biobarrier. 
Results from laboratory analyses (saturated hydraulic conductivity) of soil samples taken during construction of the test plots were not available when the irrigations were conducted. The volume of water applied by each applicator was monitored using a paddle wheel flow meter and recorded on a datalogger. Total amounts and rates of water applied to each test plot are shown in Table 1.

Irrigations were conducted two plots at a time. One capillary/biobarrier test plot and its corresponding thick soil test plot were wetted simultaneously, i.e., plots B1 and S1, B2 and S2, B3 and S3, and B4 and S4. Supplemental test plots I5 and D5 were wetted individually. Water was applied to each plot by energizing the water supply pump for one minute every 15 minutes until drainage occurred. Water applications to that plot were then terminated. During water applications, scattered areas of shallow ponding were observed on plot surfaces. All ponded water infiltrated within 15 minutes, i.e., before the next pumping cycle. Cumulative amounts of water applied to each test plot are shown in Figure 2. Although wetting was initiated simultaneously on both capillary/biobarrier and thick soil test plots, the capillary/biobarrier test plots started draining first because water moved through the capillary/biobarrier (comprised of gravel and cobbles) more rapidly than through an equal depth of soil in the thick soil test plots. Turning off the water to the capillary/biobarrier test plot inadvertently increased flow to the thick soil test plot, hence the bimodal curves for the thick soil (S) test plots.

Two notable problems occurred during the irrigations. First, a power outage that occurred while wetting plot S4 terminated water application prior to initiation of drainage. Since moisture content measurements from within the plot indicated that the wetting front was close to the bottom of the plot at the time of the outage and that drainage was imminent, wetting was not reinitiated after the outage.

Second, a solenoid failure during wetting of test plots B1 and S1 resulted in continuous water application to plot B1 after $1700 \mathrm{~h}$ on 24 Sep. 1997. Water application stopped when the supply tank ran dry. As a result, plot B1 received more water than plot S1. Drainage from plot B1 began during water application. Drainage from plot S1 had not started when the supply tank ran dry. Since freezing temperatures were

Table 1. Irrigation dates and amounts of water applied (FY-97).

\begin{tabular}{|c|c|c|c|c|c|}
\hline \multirow[b]{2}{*}{ Plot } & \multirow[b]{2}{*}{ Water Application Period } & \multicolumn{2}{|c|}{ Total Applied } & \multirow{2}{*}{$\begin{array}{l}\text { Time } \\
\text { (d) }\end{array}$} & \multirow{2}{*}{$\begin{array}{l}\text { Rate Applied } \\
(\mathrm{cm} / \mathrm{d})\end{array}$} \\
\hline & & $(\mathrm{L})$ & $(\mathrm{cm})$ & & \\
\hline \multirow[t]{2}{*}{ B1 } & $9-22-9711: 15$ to $9-24-9717: 00$ & 2,961 & 31.87 & 2.25 & 14.17 \\
\hline & 9-24-97 17:00 to 9-24-97 20:32 & 2,854 & 30.72 & 0.14 & 219.43 \\
\hline S1 & $9-22-9711: 15$ to $9-24-9720: 32$ & 3,285 & 35.36 & 2.39 & 14.79 \\
\hline B2 & $7-21-97$ 9:00 to $7-24-97$ 13:50 & 4,499 & 48.43 & 3.20 & 15.13 \\
\hline \multirow[t]{2}{*}{ S2 } & $7-21-979: 00$ to $7-24-97$ 13:50 & 4,782 & 51.47 & 3.20 & 16.09 \\
\hline & $7-24-9713: 50$ to $7-25-978: 26$ & 1,768 & 19.03 & 0.78 & 24.40 \\
\hline B3 & $7-14-9712: 00$ to $7-17-9712: 00$ & 3,904 & 42.02 & 3.00 & 14.01 \\
\hline \multirow[t]{2}{*}{ S3 } & $7-14-9712: 00$ to $7-17-9712: 00$ & 4,619 & 49.72 & 3.00 & 16.57 \\
\hline & $7-17-9712: 00$ to $7-18-979: 00$ & 1,820 & 19.59 & 0.87 & 22.52 \\
\hline B4 & $7-8-9712: 00$ to $7-10-9718: 00$ & 3,624 & 39.01 & 2.25 & 17.34 \\
\hline \multirow[t]{2}{*}{ S4 } & $7-8-9712: 00$ to $7-10-9718: 00$ & 2,940 & 31.65 & 2.25 & 14.06 \\
\hline & $7-10-9718: 00$ to $7-11-977: 37$ & 996 & 10.72 & 0.57 & 18.81 \\
\hline D5 & $6-23-9715: 26$ to $6-25-9715: 00$ & 4,012 & 43.18 & 1.98 & 21.81 \\
\hline I5 & $7-29-9711: 00$ to $7-30-9711: 00$ & 2,164 & 23.29 & 1.00 & 23.29 \\
\hline
\end{tabular}



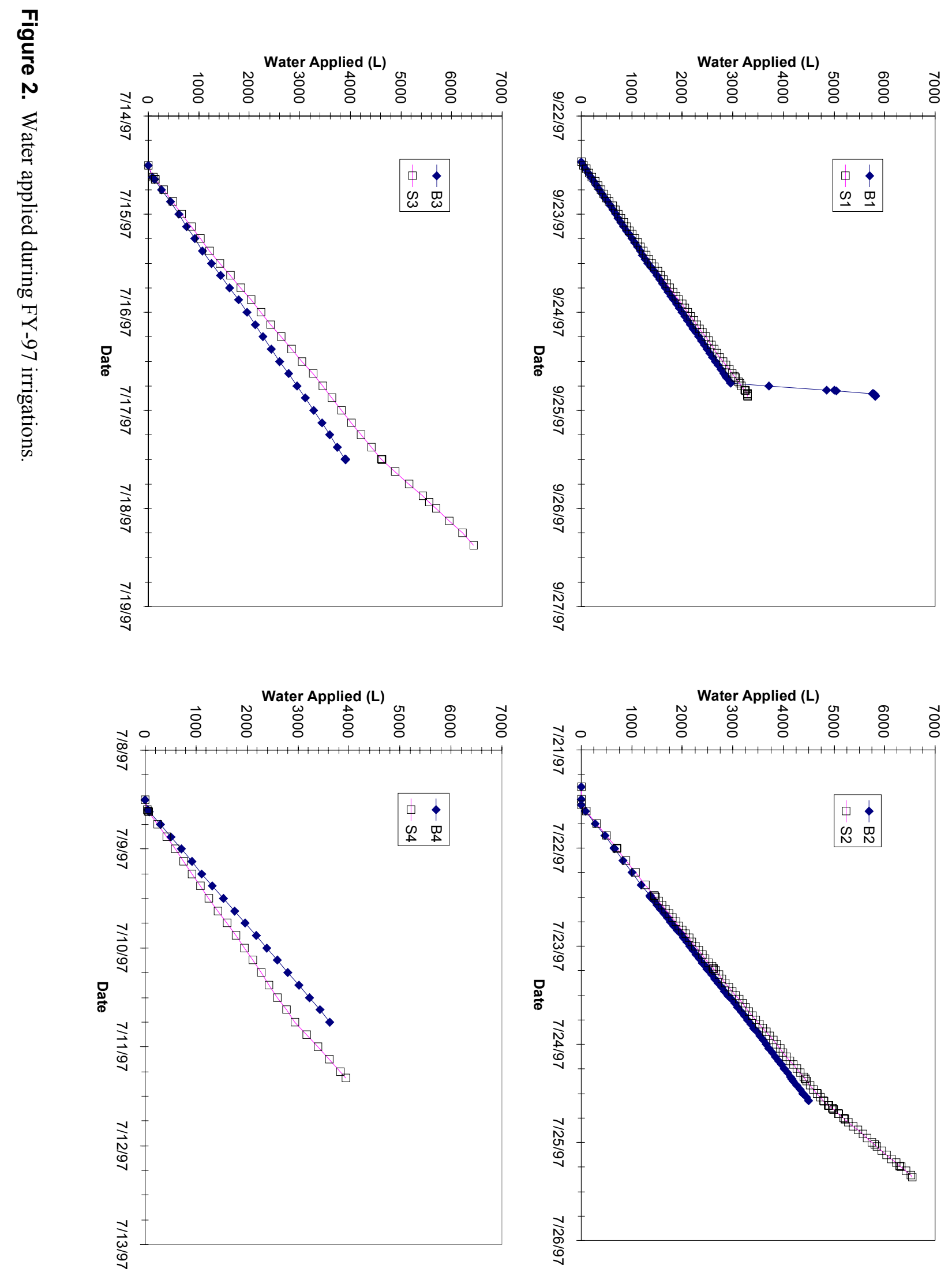
predicted for the next few days and the application system is not designed for cold weather operation, the decision was made to terminate the irrigation.

All of the test plots subsided as a result of the irrigations. Subsidence was measured at 25 locations on each plot using a 75-cm by $75-\mathrm{cm}$ grid. A pipe was laid across each plot with its ends resting on the concrete edges of the plot to serve as a grid point locator and to establish a vertical reference point. Averages of the inner 3 by 3 grid subsidence measurements were used for comparisons. Measurements made along the outer edges of the plots are not included in the averages because subsidence along the edges appeared to be affected by the edges and not representative of overall plot subsidence.

\subsection{Barrier Performance Assessment}

The function of the engineered barriers undergoing evaluation is to minimize the downward movement of water through the barriers. Rather than providing just an impermeable barrier to stop downward water movement, these barriers are designed to rely on several natural, interactive processes to function effectively. Determining the engineered barrier's water balance has been identified as one of the most effective ways to evaluate the barrier's overall performance (Nyhan et al., 1990; Ward and Gee, 1997). The water balance of the engineered barrier test plots quantitatively accounts for all water impacting the test plots. The water balance equation is represented as:

$$
\Delta S=P+I-R-D-E T
$$

where $\Delta \mathrm{S}$ is the change in soil water storage, $\mathrm{P}$ is precipitation, $\mathrm{I}$ is irrigation, $\mathrm{R}$ is surface runoff, $\mathrm{D}$ is drainage, and ET is evapotranspiration. Changes in soil water storage in the following water balance evaluation are based on water contents determined from the measurement of bulk soil dielectric constants using time-domain reflectometry (TDR). Three TDR probes were installed at depths of 20, 40, 60, 80, $100,120,140,155,255$, and $295 \mathrm{~cm}$ in each test plot. Three additional probes were installed at depths of 180,205 , and $230 \mathrm{~cm}$ in each thick soil test plot. The TDR probes were monitored hourly in FY-97 and once every three hours in FY-98 and FY-99. The water balance calculations were made on a fiscal year basis rather than a calendar year basis to avoid soil-freezing effects on TDR readings. The change in water stored in each test plot, $\Delta \mathrm{S}$, at any given time was calculated as

$$
\Delta S={ }_{0 t_{1}}^{L_{2}} \frac{\partial \theta(z, t)}{\partial t} d t d z
$$

where $\mathrm{L}$ is the depth of the test plot, $\theta$ is the volumetric water content, $\mathrm{z}$ is the depth interval of the water content measurement, and $\mathrm{t}$ is time. Moisture contents in the $0.91-\mathrm{cm}$-thick capillary/biobarrier were not determined because TDR probes were not installed in that zone. This is of little consequence in the following discussion because the water holding capacity of the barrier zone is minimal. Precipitation at the test facility is measured using a tipping bucket rain gauge equipped with a heater. This rain gauge is located on the surface of the backfill surrounding the test plots. Irrigation was measured by flow meters. Surface runoff is zero because the test cell sidewalls extend above the surface of the test plots. Drainage is measured by both tipping buckets installed at the outlet of the plot drains (to measure volume of drainage) and pressure transducers installed on the floor of the drainage sumps (to measure water level in the sump). Evapotranspiration is determined by solving Equation 1 for ET with measured values substituted for all other components. During FY-97, FY-98, and FY-99 the ET term represents evaporation only because all plot surfaces were kept cleared of vegetation, thereby eliminating transpiration by plants. 
Thermocouples were used to measure soil temperatures during the study. Two thermocouples were installed at depths of 5, 20,40,60,80,155, and $270 \mathrm{~cm}$ in each test plot. Five additional thermocouples were installed at depths of 60 and $270 \mathrm{~cm}$ in each plot.

Cables from all instruments buried in a test plot were routed to a plot cable tower. Each tower is centrally located within a plot and serves to minimize cable intrusions within the plot as well as provide a centralized path for cables exiting the plot. The tower is a PVC tube that is installed vertically within the plot and does not extend to the plot surface, thereby minimizing surface penetrations and possible artificially created pathways for water flow into the plot. Instrument cables enter the tower through sealed penetrations and are routed through a sealed penetration in the floor of the plot to the data acquisition system in the access trench. Readings from all of the above instruments are made automatically by the data acquisition system. 


\section{RESULTS AND DISCUSSION}

\subsection{Precipitation}

Cumulative precipitation measured at the test facility during FY-97, FY-98 and FY-99 is shown in Figure 3 along with the long-term average precipitation measured $11 \mathrm{~km}$ northeast of the test facility at the Central Facilities Area (CFA). CFA is the nearest location to the test facility where meteorological data have been collected for a long time (since 1950). Total precipitation for each of the three periods was close to the long-term average. The patterns of precipitation for each period, however, differed from the long-term average and from each other. In FY-97 precipitation in December and the first few days of January was significantly greater than the long-term average. This was followed by over four months of below-average precipitation, which brought the total back to normal. Another period of rainfall in August raised the level above normal where it remained until the end of FY-97. In FY-98 precipitation in November and December was less than the long-term average and the cumulative amount remained below average until May. Precipitation remained near normal throughout early summer, fell slightly below normal toward the end of summer, and recovered to match the long-term average at the end of FY98. Precipitation in FY-99 followed the long-term average curve closer than in the previous two years through spring when it increased above the long-term average. Minimal precipitation after June 6 kept the yearly total below the long-term average.

The impacts on the barriers of the variations in precipitation from year to year are magnified by several factors. Air and soil temperatures can significantly affect the amount and timing of infiltration due to precipitation. Precipitation during warm periods results in rainfall that can readily infiltrate into the soil. Precipitation during cold periods produces snow, which does not readily infiltrate into the soil. Infiltration resulting from snowfall is delayed as long as the snow does not melt. Snow accumulation from numerous precipitation events can result in a significantly greater amount of infiltrating water when thawing occurs than individual precipitation events may indicate. Evaporation and transpiration during and immediately after periods of thaw are likely to be low, thus putting greater stress on the barrier system than during summer or fall. Soil freezing can also prevent infiltration, thereby allowing water to accumulate prior to infiltration. The freezing of precipitation and soil effectively decouples the timing of precipitation and infiltration events. Figure 4 verifies that soils froze to at least the $40-\mathrm{cm}$ depth during the period FY-97 to FY-99, and that soils stayed frozen for sustained periods. Thawing occurred with relative abruptness in March each year. Warm temperatures in early January caused an additional thaw in FY-97. As discussed below, the most significant infiltration events during FY-98 and FY-99 occurred in March, and during FY-97 (excluding the irrigations) occurred in January.

Snow depths for FY-97 to FY-99, and the long-term average snow depths measured at CFA (daily snow depths are not measured at the test facility) are shown in Figure 5. In FY-97 snow covered the ground throughout December, but only sporadically before and after December. This is in contrast to the long-term average where snow covers the ground from November to April, with the greatest snow depth in late January. The thaw in early January resulted in significant infiltration of water. Temperatures turned cold again after this infiltration, as reflected by the soil freezing in Figure 4, but the absence of snow precluded infiltration during the subsequent March thaw. Snow covered the ground for a much longer time in FY-98. Spot checks of snow depths on the test plots showed general agreement with levels recorded at CFA with one major exception. CFA reported complete disappearance of snow by 1 Mar. 1998. On 16 Mar. 1998 there were still several centimeters of snow on the test plots. The snow was melting and there was standing water beneath the snow. The combination of melting snow and thawing soil resulted in significant infiltration in March. Although snow melting had occurred earlier in midwinter, the soil had remained frozen and infiltration was minimized. A similar situation occurred in FY99. 


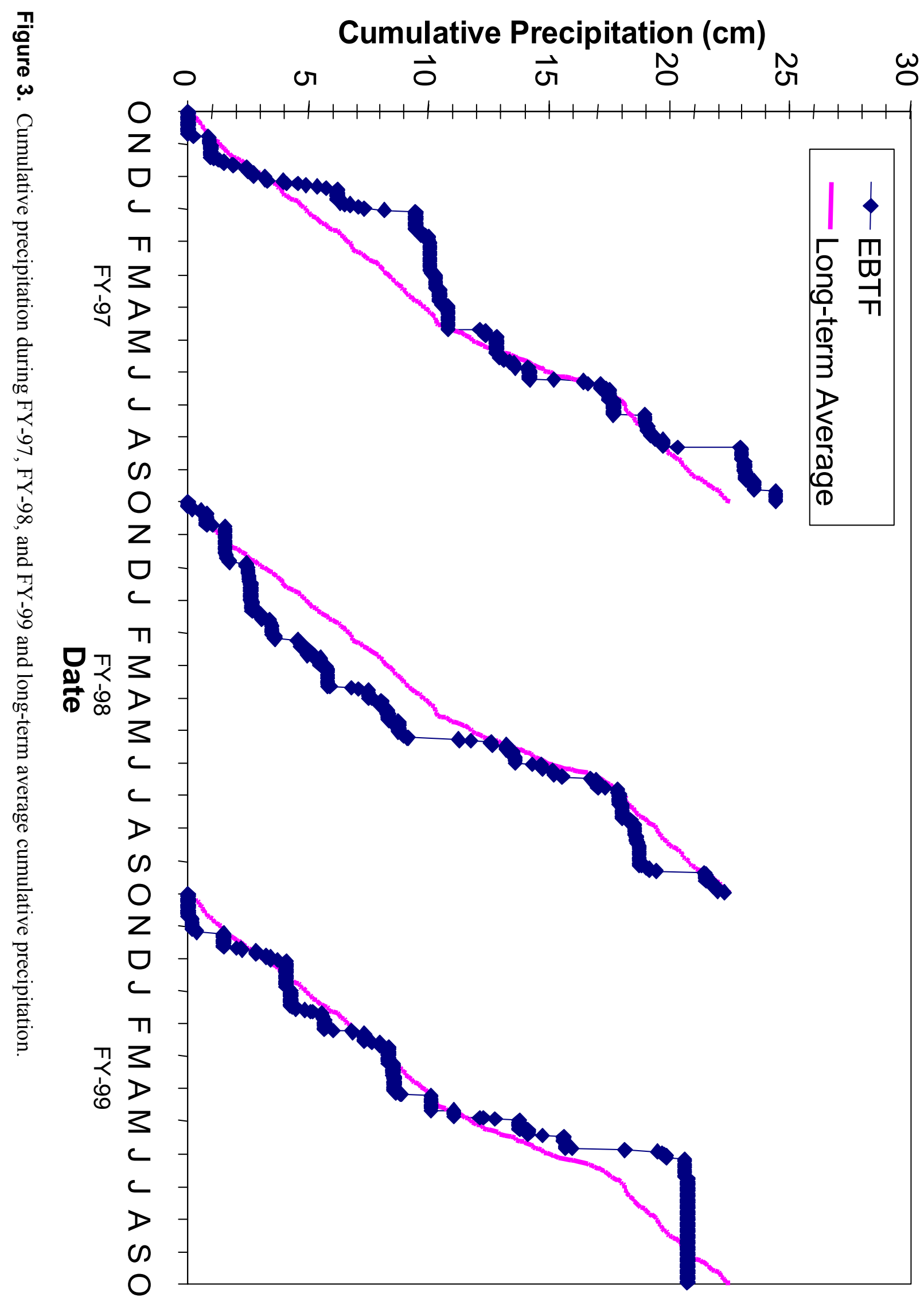




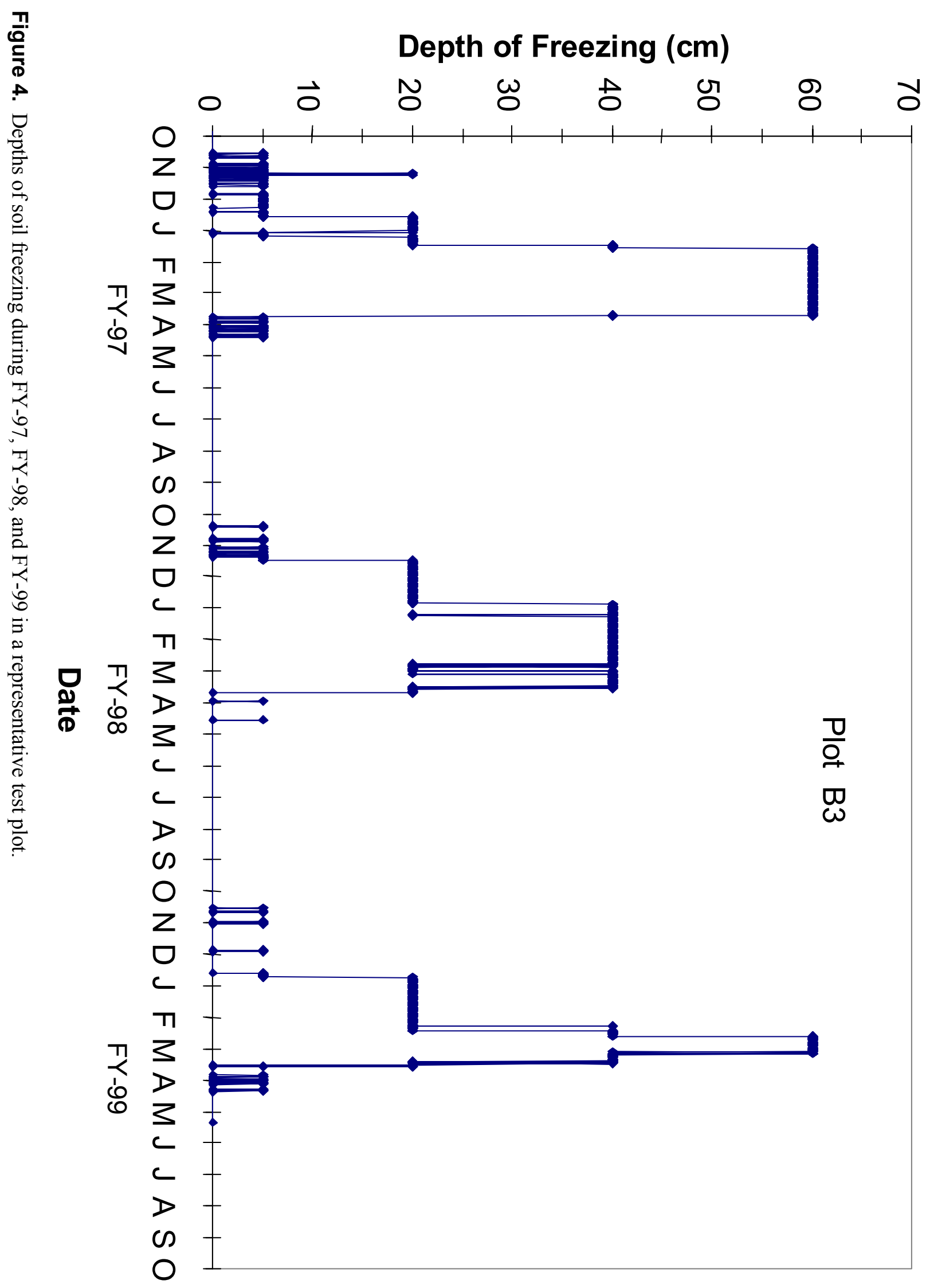




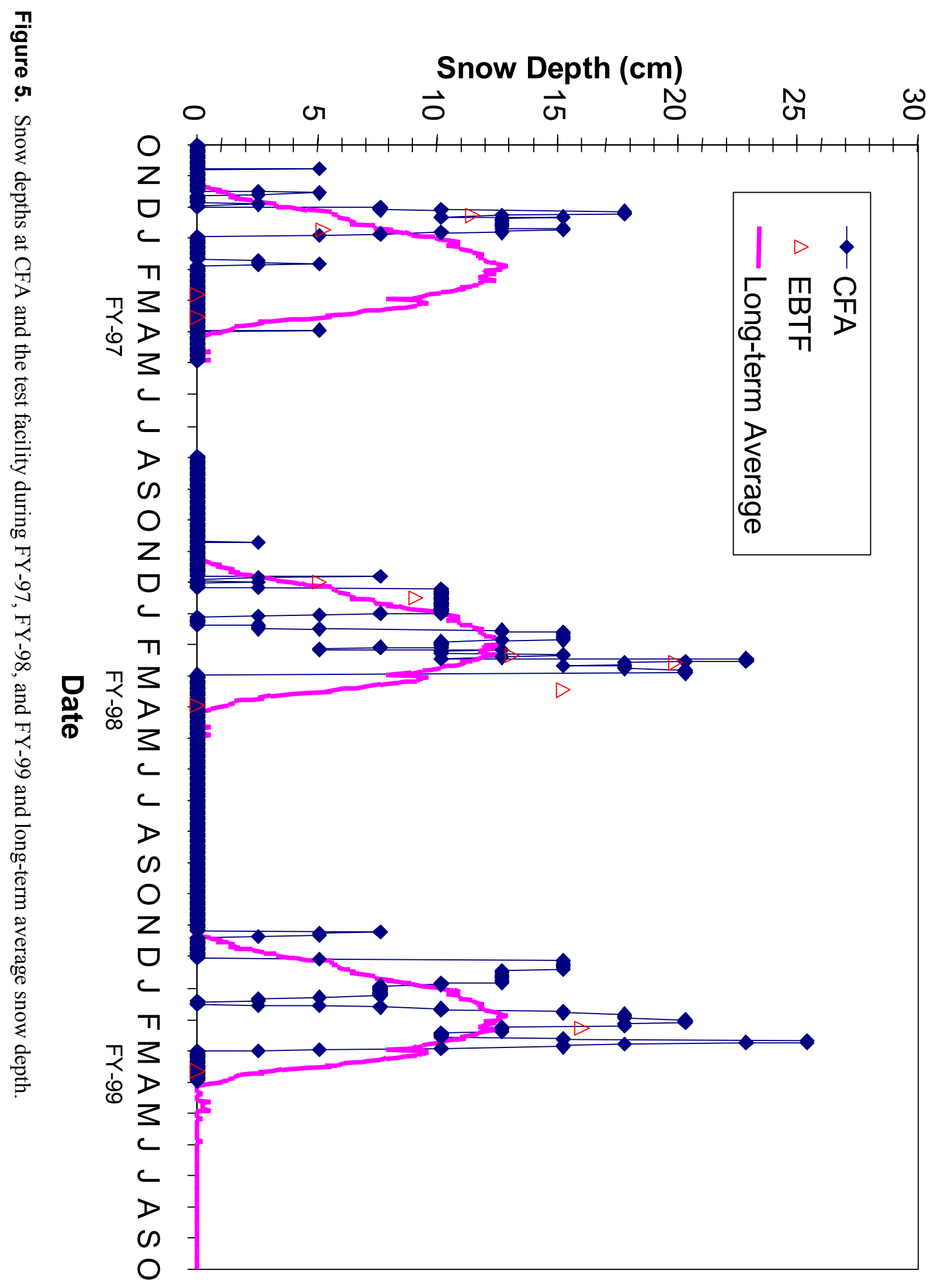




\subsection{Water Storage}

The test plots were filled with air-dried soil and instrumented in the spring of 1996. Consequently, water storage in the test plots at the start of FY-97 was low. Precipitation in November and December of 1996 and the first few days of January 1997 resulted in the first increases in water storage. Soil freezing was sporadic (see Figure 4), thus allowing the precipitation to infiltrate into the soil. Without transpiration from vegetation as a means of recycling water back to the atmosphere, water storage gradually increased as a result of infiltrating precipitation throughout the spring and early summer of 1997. Water content profiles of the plots during this period reveal that the distribution of water within the plots differed between the two designs. Figure 6 shows water content profiles in both types of test plots on two dates, the latter profile comprises data collected just prior to the start of the irrigations. Each point represents the average value from the four plots. Note that water contents in January differ somewhat between the two types of plots. Although the plots were constructed using soil of uniform water content, rainfall during construction caused differences in water contents at different levels depending on degree of plot completion. By July, water had clearly infiltrated to the $1.55-\mathrm{m}$ depth in the B plots (Figure 6a). This is the position of the TDR probe closest to the top of the capillary/biobarrier (which begins at the $1.60-\mathrm{m}$ depth). Water content did not change at the 2.25- $\mathrm{m}$ depth. This is the position of the TDR probe closest to the bottom of the capillary/biobarrier (which ends at the 2.50-m depth). Although no TDR measurements were made within the capillary/biobarrier, it is reasonable to assume that under these unsaturated conditions the water content of this zone did not change and that the capillary barrier was effectively stopping downward water movement. On average, the volumetric water content at the $1.55-\mathrm{m}$ depth was $4.2 \%$ greater in the B plots than in the S plots, and the change in storage from the surface to the depth of the capillary barrier during this period (1/1/97 to 7/8/97) was $3.04 \mathrm{~cm}$ greater in the capillary/ biobarrier plots than in the thick soil plots. In the absence of a capillary barrier, water infiltrated to the 2.05-m depth during this period in the S plots (Figure 6b).

The amount of water stored in the soil increased significantly for both types of covers in FY-97 as a result of the irrigations (Table 2). The capillary/biobarrier test plots show smaller increases in storage compared to the thick soil plots because little water is stored in the $0.90-\mathrm{m}$-thick gravel/cobble layer. The large increases in storage are possible because the soil in all plots was close to air-dried moisture contents at the start of the monitoring period. Without the aid of transpiration by plants as a means for removing water from the soil, moisture storage levels in the test plots remained elevated after the irrigations. On average, storage in the capillary/biobarrier plots decreased only $4.04 \mathrm{~cm}$ and $0.64 \mathrm{~cm}$ in FY-98 and FY99 , respectively, and storage in the thick soil plots decreased $1.73 \mathrm{~cm}$ and $1.00 \mathrm{~cm}$ in those same periods. Although storage changes after the irrigations in both types of plots were relatively small, there were significant differences in redistribution of water within the two types of plots. These differences determined how water losses from the plots were partitioned between drainage and evaporation.

\subsection{Drainage}

No drainage occurred in FY-97 prior to the irrigations. Not surprisingly, drainage was observed in all test plots within days of initiation of irrigation. By the beginning of FY-98, drainage from the irrigations had slowed to very low levels. This can be seen in more detail in Table 3, which shows total drainage from each test plot during the first five months of FY-98. Test plots B1 and S1 show noticeably more drainage than the other plots because irrigations on these two plots were conducted later (in the latter half of September 1997) than irrigations on the other plots (which were conducted in July). By February 1998, very little drainage is evident in test plots B1 and S1 and none whatsoever in the other test plots. Note also that water continued to drain for a longer time from the capillary/biobarrier test plots than from the thick soil plots. 

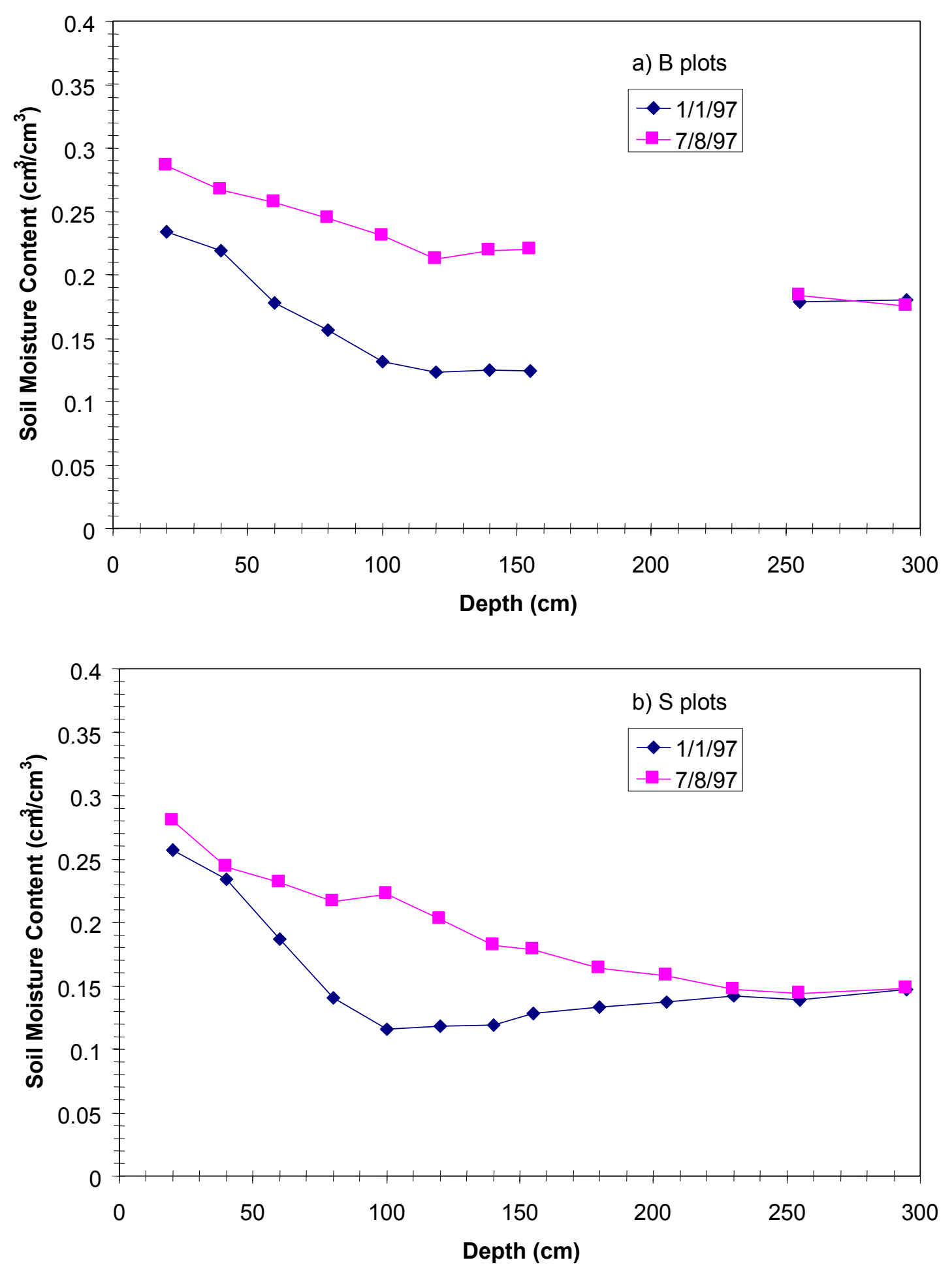

Figure 6. Average TDR-measured water content profiles in B plots (a) and S plots (b). 
Table 2. Water balance components for FY-97, FY-98 and FY-99.

\begin{tabular}{|c|c|c|c|c|c|c|}
\hline Plot & FY & $\begin{array}{l}\Delta \mathrm{S}^{\mathrm{a}} \\
(\mathrm{cm})\end{array}$ & $\begin{array}{l}\text { Precipitation } \\
(\mathrm{cm})\end{array}$ & $\begin{array}{c}\text { Irrigation } \\
(\mathrm{cm})\end{array}$ & $\begin{array}{c}\text { Drainage } \\
(\mathrm{cm})\end{array}$ & $\begin{array}{c}\text { ET } \\
(\mathrm{cm})\end{array}$ \\
\hline \multirow[t]{3}{*}{ B1 } & 1997 & 44.60 & 24.40 & 62.59 & 25.15 & 17.24 \\
\hline & 1998 & -4.47 & 24.22 & 0 & 8.71 & 19.98 \\
\hline & 1999 & 1.61 & 20.97 & 0 & 2.52 & 16.84 \\
\hline \multirow[t]{3}{*}{$\mathrm{S} 1$} & 1997 & 61.55 & 24.40 & 35.36 & 0 & -1.79 \\
\hline & 1998 & -3.67 & 24.22 & 0 & 14.68 & 13.21 \\
\hline & 1999 & -1.07 & 20.97 & 0 & 6.49 & 15.56 \\
\hline \multirow[t]{3}{*}{ B2 } & 1997 & 42.22 & 24.40 & 48.43 & 11.35 & 19.26 \\
\hline & 1998 & -4.21 & 24.22 & 0 & 7.16 & 21.27 \\
\hline & 1999 & -1.14 & 20.97 & 0 & .047 & 22.07 \\
\hline \multirow[t]{3}{*}{$\mathrm{S} 2$} & 1997 & 62.42 & 24.40 & 70.50 & 22.69 & 9.79 \\
\hline & 1998 & 0.53 & 24.22 & 0 & 8.18 & 15.51 \\
\hline & 1999 & -0.75 & 20.97 & 0 & 8.92 & 12.80 \\
\hline \multirow[t]{3}{*}{ B3 } & 1997 & 45.08 & 24.40 & 42.02 & 4.84 & 16.50 \\
\hline & 1998 & -2.64 & 24.22 & 0 & 4.03 & 22.83 \\
\hline & 1999 & -2.71 & 20.97 & 0 & 0.11 & 23.57 \\
\hline \multirow[t]{3}{*}{ S3 } & 1997 & 63.95 & 24.40 & 69.31 & 20.28 & 9.48 \\
\hline & 1998 & -1.49 & 24.22 & 0 & 13.86 & 11.85 \\
\hline & 1999 & -1.70 & 20.97 & 0 & 9.67 & 13.00 \\
\hline \multirow[t]{3}{*}{ B4 } & 1997 & 45.66 & 24.40 & 39.01 & 5.37 & 12.38 \\
\hline & 1998 & -4.83 & 24.22 & 0 & 5.35 & 23.70 \\
\hline & 1999 & -0.33 & 20.97 & 0 & 0.11 & 21.20 \\
\hline \multirow[t]{3}{*}{ S4 } & 1997 & 54.66 & 24.40 & 42.37 & 6.57 & 5.54 \\
\hline & 1998 & -2.27 & 24.22 & 0 & 11.91 & 14.58 \\
\hline & 1999 & -0.49 & 20.97 & 0 & 8.41 & 13.05 \\
\hline
\end{tabular}

Table 3. Drainage amounts during late fall and winter of FY-98.

\begin{tabular}{llllll}
\hline \multicolumn{5}{c}{} & \multicolumn{5}{c}{$\begin{array}{c}\text { Drainage } \\
(\mathrm{cm})\end{array}$} \\
\cline { 2 - 6 } Plot & Oct-97 & Nov-97 & Dec-97 & Jan-98 & Feb-98 \\
\hline B1 & 0.6460 & 0.0570 & 0.0130 & 0.0036 & 0.0009 \\
S1 & 2.1940 & 0.2260 & 0.0130 & 0.0004 & 0 \\
B2 & 0.0730 & 0.0110 & 0.0010 & 0 & 0 \\
S2 & 0 & 0 & 0 & 0 & 0 \\
B3 & 0.0400 & 0 & 0 & 0 & 0 \\
S3 & 0 & 0 & 0 & 0 & 0 \\
B4 & 0.0530 & 0.0110 & 0 & 0 & 0 \\
S4 & 0.0180 & 0.0010 & 0 & 0 & 0 \\
\hline a From tipping bucket data. & & & & \\
\hline
\end{tabular}


Drainage from all test plots resumed in mid-March 1998 (Figure 7). The resumption of drainage coincided with the thawing of frozen soil (Figure 4). Soil freezing can affect drainage in at least two ways. First, freezing can establish a barrier in the soil to subsequent infiltration of water from rainfall or snowmelt and to the downward flow of water. Second, freezing can immobilize water that is already in the soil, thus preventing its downward movement. This second mechanism was probably of little consequence during the winter of FY-98 because drainage had already slowed to very low levels by the time freezing started to reach the $20-\mathrm{cm}$ depth in mid-November. The first mechanism played a much more significant role in the test plots. Drainage in October 1997, before any significant freezing occurred, was already at much lower levels than the drainage that occurred in March 1998. Therefore, the March drainage must have had a source other than the irrigations. That other source was precipitation during the late fall/winter of FY-98. Figures 3 and 5 indicate that precipitation occurred throughout this period and, with minor exceptions, the ground was covered with snow. As noted earlier, standing water under melting snow was observed on the test plots on March 16, 1998. By March 21, the next observation, all the snow had melted. Although drainage from the irrigations had practically ceased prior to soil freezing, all of the test plots still held considerable amounts of water. This allowed the infiltrating water to move fairly rapidly through the plots and initiate drainage.

The FY-98 drainage curve for the thick soil covers exhibits a noticeable inflection in May. This inflection undoubtedly is due to 11 consecutive days of rainfall beginning May 6 and totaling $4.37 \mathrm{~cm}$. The largest single-day total during this period was $2.06 \mathrm{~cm}$ on May 10. This rainfall increased the drainage that still was occurring as a result of the March thaw. Notice that the drainage curve for the capillary/biobarrier covers does not exhibit this inflection. The capillary/biobarrier covers are more effective in preventing deep infiltration of this rainfall.

Since all the test plots are located near one another, they all received essentially equal inputs of water due to the winter precipitation. Equal inputs, however, resulted in about twice the total amount of drainage from the thick soil test plots (average from 1 March 1998 to 30 September $1998=11.3 \mathrm{~cm}$ ) as from the capillary/biobarrier test plots (average from 1 March 1998 to 30 September $1998=6.0 \mathrm{~cm}$ ). Even test plots S1 and S4 yielded more drainage than their corresponding capillary barrier plots (B1 and B4) despite the fact that irrigations on both S1 and S4 were terminated prior to initiation of drainage. Plots S4 and B4 received comparable amounts of water during irrigation, whereas plot S1 received considerably less water than plot B1.

Figure 7 (FY-98 drainage) also shows that drainage from the capillary/biobarrier plots slowed down more abruptly than drainage from the thick soil test plots (note the sharper knee in the curve for the capillary/biobarrier plots compared to the thick soil plots). This is consistent with observations made of drainage immediately following the irrigation. Also, drainage from the capillary/biobarrier plots again continued for a longer time than drainage from the thick soil plots. Table 4 clearly shows that all of the thick soil plots ceased draining in July (with only a small recurrence of drainage in plot S2 in September), whereas three of the four capillary/biobarrier plots continued to drain into December (plot B3 drained into November). It warrants repeating, however, that the capillary/biobarrier plots generated less total drainage for the year than the thick soil plots even though they drained for a longer time.

In FY-99 (see Figure 7), the initiation of drainage once again corresponded to the major thaw that occurred in March. As was the case in FY-98, this drainage resulted from equal inputs of water (winter precipitation) to all test plots. However, in this, the second year following the irrigations, only thick soil test plots allowed drainage. The capillary barrier prevented drainage in all B plots except plot B1. Drainage in plot B1 is the residual effect of the irrigation malfunction that resulted in more water being applied to plot B1 and at a higher rate than intended. As a result, the plot has been wetter overall and closer to capillary barrier breakthrough than the other capillary barrier test plots. The FY-99 infiltration was of sufficient magnitude to trigger breakthrough and drainage in plot B1, but not in the other B plots. 

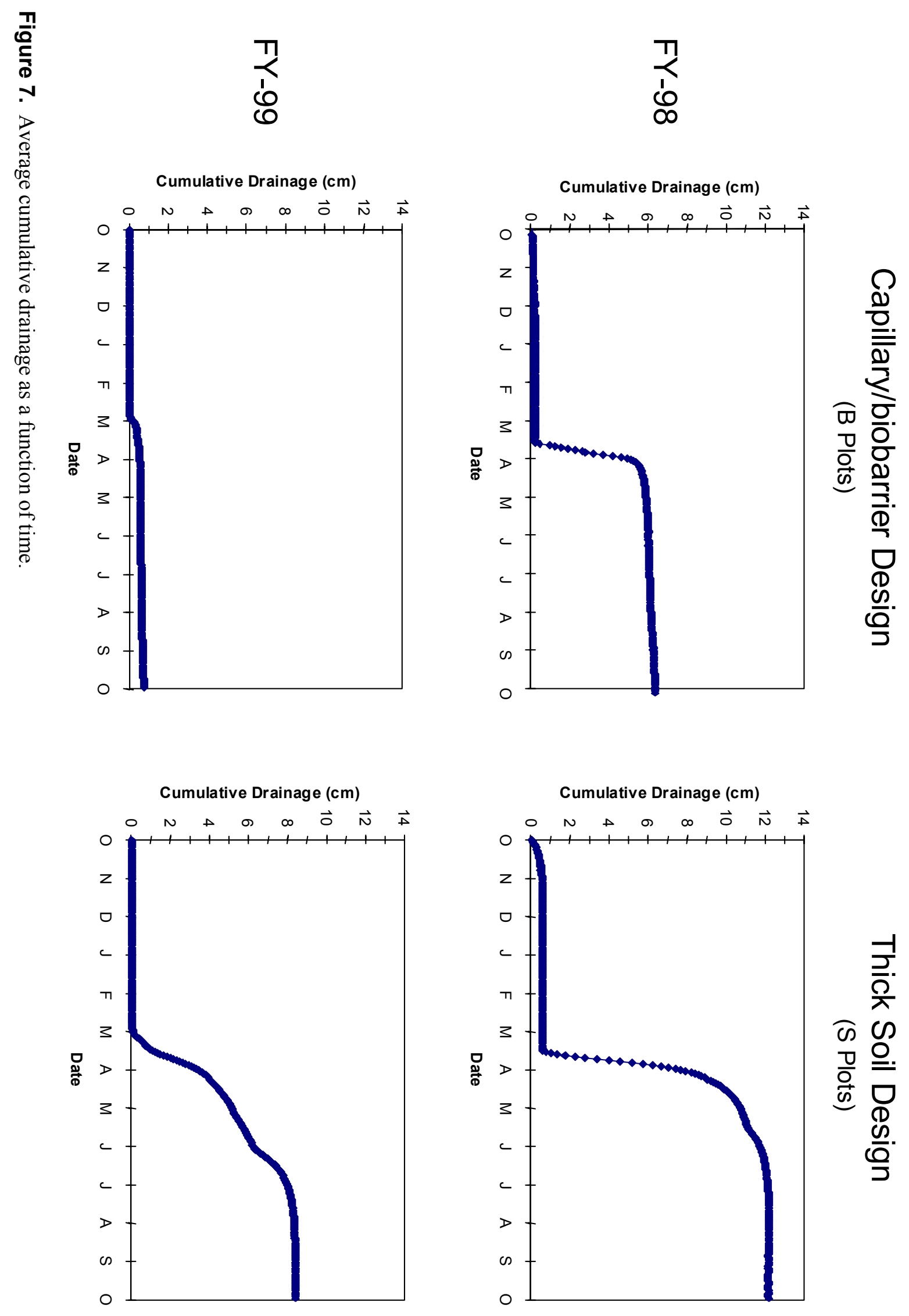
Table 4. Monthly drainage during 1998.

\begin{tabular}{|c|c|c|c|c|c|c|c|c|}
\hline \multirow[b]{2}{*}{ Month } & \multicolumn{8}{|c|}{$\begin{array}{c}\text { Drainage } \\
(\mathrm{cm})\end{array}$} \\
\hline & $\mathrm{B} 1$ & $\mathrm{~B} 2$ & B3 & B4 & S1 & $\mathrm{S} 2$ & S3 & $\mathrm{S} 4$ \\
\hline Jan & 0.0036 & 0 & 0 & 0 & 0.0004 & 0 & 0 & 0 \\
\hline Feb & 0.0009 & 0 & 0 & 0 & 0 & 0 & 0 & 0 \\
\hline Mar & 6.7985 & 5.6730 & 3.0130 & 4.1090 & 5.7376 & 4.2660 & 7.2650 & 6.4360 \\
\hline Apr & 0.7510 & 0.4930 & 0.3760 & 0.5600 & 3.3020 & 3.0730 & 4.1580 & 3.6770 \\
\hline May & 0.1240 & 0.1130 & 0.0860 & 0.1170 & 1.0850 & 0.7890 & 1.4600 & 1.0800 \\
\hline Jun & 0.0690 & 0.0780 & 0.0590 & 0.0820 & 0.5600 & 0.2280 & 0.6000 & 0.5300 \\
\hline Jul & 0.0710 & 0.0970 & 0.1170 & 0.0990 & 0.0900 & 0.0050 & 0.6000 & 0.0900 \\
\hline Aug & 0.0900 & 0.1340 & 0.1850 & 0.1390 & 0 & 0 & 0 & 0 \\
\hline Sep & 0.0680 & 0.0980 & 0.1220 & 0.1100 & 0 & 0.0020 & 0 & 0 \\
\hline Oct & 0.0290 & 0.0350 & 0.0220 & 0.0560 & 0 & 0 & 0 & 0 \\
\hline Nov & 0.0070 & 0.0050 & 0.0010 & 0.0170 & 0 & 0 & 0 & 0 \\
\hline Dec & 0.0010 & 0.0010 & 0 & 0.0030 & 0 & 0 & 0 & 0 \\
\hline
\end{tabular}

The drainage curve for the thick soil covers again exhibits a noticeable inflection, this time at the beginning of June. This inflection most likely is due to a 10-day period beginning May 28 that totaled $4.95 \mathrm{~cm}$ of rainfall. The largest single-day total during this period was $2.18 \mathrm{~cm}$ on May 29. As in the previous year, this rainfall increased the drainage that still was occurring as a result of the March thaw. The capillary/biobarrier covers, on the other hand, prohibited this rainfall from contributing to drainage.

\subsection{Evaporation}

Calculated evaporation is shown in Table 2. The ET term represents just evaporation, E, because test plots were kept cleared of vegetation during FY-97 to FY-99. The negative value for evaporation for test plot S1 in FY-97 stands out as an anomaly. This probably results from the accumulated imprecision of measurements when small values of ET are determined by summation. This value is excluded from further discussions. On average, evaporation from the capillary/biobarrier test plots is greater than evaporation from the thick soil test plots in all three years $(16.35 \mathrm{~cm}$ vs. $8.27 \mathrm{~cm}, 21.95 \mathrm{~cm}$ vs. $13.79 \mathrm{~cm}$, and $20.92 \mathrm{~cm}$ vs. $13.60 \mathrm{~cm}$, in FY-97, FY-98 and FY-99, respectively). This observation is consistent with the other factors of the water balance equation discussed above. The capillary/biobarrier test plots have allowed less drainage than the thick soil test plots even when equal amounts of infiltration have occurred. Water that is redistributed downward and contributes to drainage in the thick soil plots is held in the upper portions of the capillary/biobarrier plots by the capillary barrier. Figure 8 illustrates the higher moisture contents found in the upper portions of the capillary barrier plots compared to the thick soil plots. The closer water is to the surface, the more it is subject to the evaporative forces of the atmosphere. Consequently, greater evaporation is observed from the capillary/biobarrier test plots than from the thick soil test plots.

Note that evaporation values are based on the summation of terms in Eq. 1, and are not measured. These calculations do not include water storage in the gravel and cobble layers, which are devoid of 


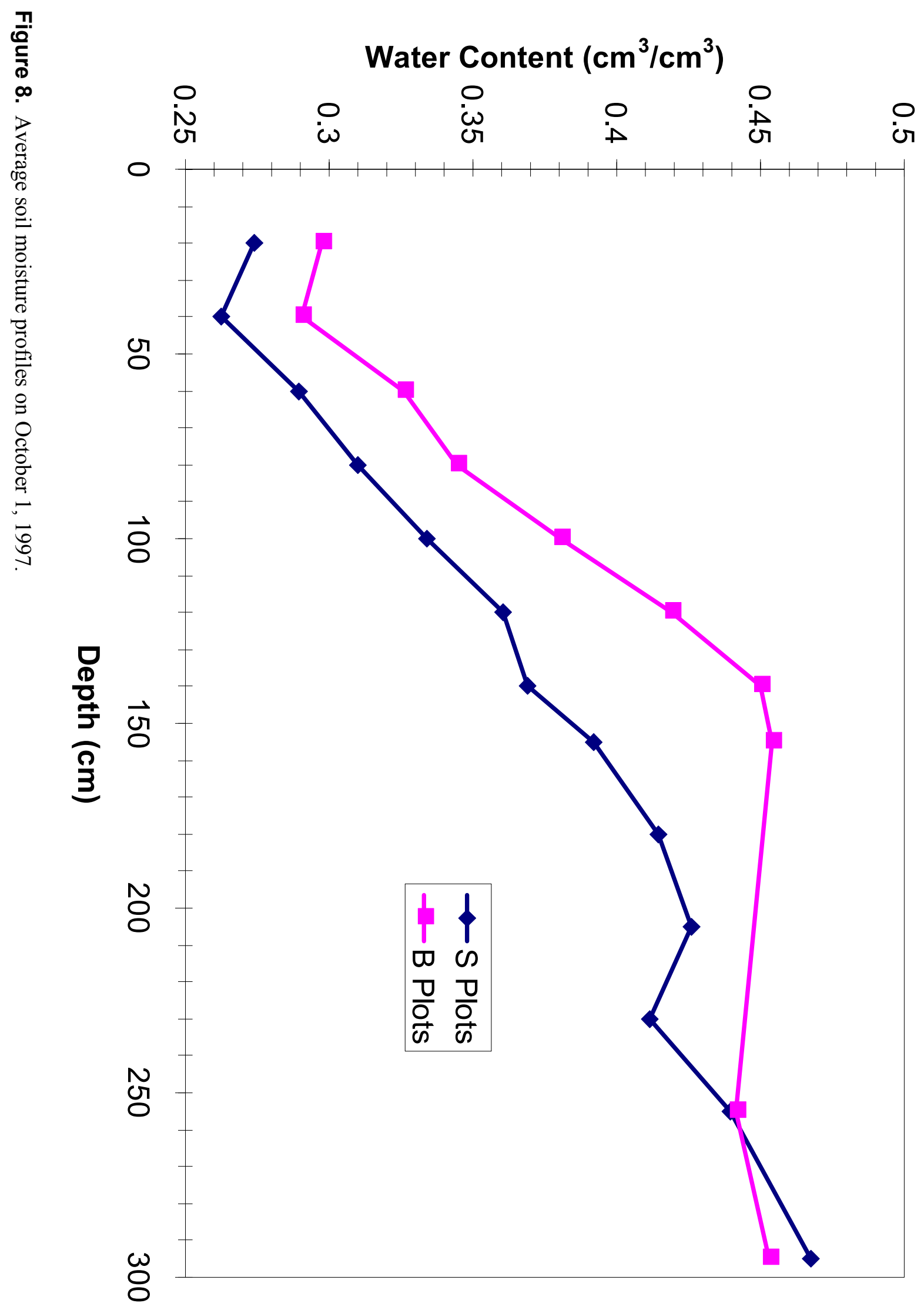


instruments. A portion of the calculated evaporation actually may be water stored in the gravel and cobble layers, thus reducing the amount of evaporation reported for the capillary/biobarrier test plots. This difference is likely small, but is not explicitly known.

Evaporation as a percentage of precipitation (precipitation plus irrigation in FY-97) differed significantly between FY-97 and the next two years. In the capillary/biobarrier test plots, evaporation represented $90.6 \%$ and $99.7 \%$ of precipitation in FY-98 and FY-99, respectively, but only $22.6 \%$ of precipitation (plus irrigation) in FY-97. In the thick soil test plots, evaporation represented $56.9 \%$ and $64.8 \%$ of precipitation in FY-98 and FY-99, respectively, but only $9.6 \%$ of precipitation (plus irrigation) in FY-97. The lower percentages in FY-97 result from the fact that much of the water that infiltrated ended up filling empty storage capacity in the plots, particularly in the lower reaches of the plots where the water is out of reach of evaporative forces.

\subsection{Subsidence}

As noted above, all of the test plots subsided as a result of the irrigations. Thick soil test plots subsided an average of $16.1 \mathrm{~cm}$ whereas capillary/biobarrier test plots subsided an average of $7.3 \mathrm{~cm}$. Silt loam soils are reasonably strong and incompressible when dry, but they are highly susceptible to collapse when wetted (Mitchell, 1976; Rodriguez et al., 1988). Collapse resulting from saturation is likely when the density of the soil is sufficiently low to give a void space larger than that needed to hold the liquid limit water content (Gibbs and Bara, 1967). The test plot soils were compacted to $82 \%$ of maximum, as per design specifications, during installation. The level of compaction was designed to strike a balance between the minimization of collapse and the creation of a zone suitable for plant root penetration when the plots are vegetated. Evidently, these soils are still susceptible to collapse at this level of compaction.

The difference in construction between the two types of test plots is the inclusion of the gravel and cobble layers in the capillary barrier plots. Greater subsidence in the thick soil plots seems to indicate that settlement took place in the silt loam and not in the gravel and cobble layers, although this has not been confirmed. Assuming settlement occurred over the full length of the silt loam (including the gravel/soil mixture at the surface), the percentage of settlement is $3.48 \%$ in the capillary barrier plots versus $5.37 \%$ in the thick soil plots. Assuming settlement only occurred above the capillary barrier, the percentage of settlement is $4.56 \%$. If the amount of settlement is proportional to the depth of soil, the percentages between the two designs should be equal. The results above indicate that the occurrence of settlement above the capillary barrier but not below it fits this assumption better than settlement over the full length of soil. This, also, has not been confirmed. The planned excavation of selected plots when all experiments are completed will allow us to determine soil properties and compare them to initial properties. This should shed some light on how the settlement occurred.

\subsection{Conclusions}

Test plot monitoring and water balance analyses revealed significant differences between the performance of the thick soil and capillary/biobarrier test plots both before and after the irrigation to breakthrough. In the year prior to the irrigations, none of the test plots produced drainage as a result of exposure to ambient conditions. However, differences in the performance of the two barrier designs were already beginning to be revealed in the internal distribution of water within the plots. The capillary barrier was effective in prohibiting the downward migration of water.

Winter weather conditions at the site caused numerous precipitation events to accumulate in the form of snow on the soil surface. Combined with soil freezing, this effectively decoupled infiltration from individual precipitation events during this period. The relatively rapid thawing of accumulated snow and 
soils at the onset of warm weather resulted in the most significant infiltration events observed during testing (with the exception of the irrigations).

Water storage levels in all test plots were at elevated levels compared to pre-test levels following cessation of drainage resulting from the irrigations. As a result, infiltration of melting snow during the subsequent spring overloaded the storage capacity and produced drainage in all plots. Drainage from capillary barriers slowed down faster than drainage from thick soil barriers, and, although drainage from capillary barriers continued for a longer time than drainage from thick soil barriers, the capillary barriers yielded less total drainage.

By limiting drainage, the capillary/biobarriers increased water storage in the upper portions of the test plots compared to the thick soil barriers. This led to increased recycling of water to the atmosphere through evaporation. Increased evaporation in the capillary barrier test plots reduced the amount of water stored in the plots thus providing room for all of the infiltrating water during the FY-99 spring thaw (the second season following the irrigations) without triggering drainage. Drainage occurred in all of the thick soil test plots in FY-99. During current testing, evaporation alone (without transpiration) at this site had the ability to restore the functioning capability of the capillary barrier cover. Continued monitoring of the test plots will determine to what degree both barrier types are restored to their intended functioning and the time scale required to do so.

Users of silt loam soil for engineered barriers should be aware of its structural characteristics. The silt loam soil used to construct the barriers collapsed during the irrigations as evidenced by surface subsidence. Subsidence occurred in spite of some compaction of soils during test plot installation. 


\section{REFERENCES}

Alway, F.J. and G.R. McDole. 1917. Relation of water-retaining capacity of a soil to its hygroscopic coefficient. J. Agr. Res. 9:27-71.

Anderson, J.E., R.S. Nowak, T.D. Ratzlaff, and O.D. Markham. 1993. Managing soil moisture on waste burial sites in arid regions. J. Environ. Qual. 22:62-69.

Benson, C.H., P.J. Bosscher, D.T. Lane, and R.J. Pliska. 1994. Monitoring system for hydrologic evaluation of landfill covers. Geotechnical Testing J. 17(2):138-149.

Bhatt, R.N. and I. Porro. 1998. Evaluation of engineered barriers at the Idaho National Engineering and Environmental Laboratory. In Proc. of the WM'98 Conference, Tucson, AZ. 1-5 Mar. 1998.

Campbell, M.D., G.W. Gee, M.J. Kanyid, and M.L. Rockhold. 1990. Field Lysimeter Test Facility: Second year (FY 1989) test results. PNL-7209. Pacific Northwest Lab., Richland, WA.

Daniel, D.E. 1994. Surface barriers: Problems, solutions and future needs. p. 441-487. In Proc. of the $33^{\text {rd }}$ Hanford Symposium on Health and the Environment, Richland, WA. 7-11 Nov. 1994. Battelle Press, Columbus, $\mathrm{OH}$.

Daniel, D.E. and B.A. Gross. 1995. Caps. p. 119-140. In R.R. Rumer and J.K. Mitchell (ed.) Assessment of barrier containment technologies. International Containment Technology Workshop, Baltimore, MD. August 29-31, 1995. U.S. Dep. Of Energy, Washington, DC.

Dwyer, S.F. 1997. Large-scale field study of landfill covers at Sandia National Laboratories p. 87-107. In T.D. Reynolds and R.C. Morris (ed.) Landfill capping in the semi-arid west: Problems, perspectives, and solutions Conf. Proc., Grand Teton National Park, WY. 21-22 May, 1997. Environ. Sci. and Res. Foundation, Idaho Falls, ID.

Eagleman, J.R. and Jamison, V.C. 1961. The influence of soil textural stratification and compaction on moisture flow. Missouri Agr. Exp. Sta. Res. Bull. 784.

Fisher, J.N. 1986. Hydrogeologic factors in the selection of shallow land burial for the disposal of lowlevel radioactive waste. U.S. Geol. Surv. Circular 973, U. S. Geol. Surv.

Gee, G.W., D.G. Felmy, J.C. Ritter, M.D. Campbell, J.L. Downs, M.J. Fayer, RR. Kirkham, and S.O. Link. 1993. Field lysimeter test facility status report IV: FY 1993. PNL-8911. Pacific Northwest Lab., Richland, WA.

Gibbs, H.J. and J. P. Bara. 1967. Stability problems of collapsing soils, J. Soil Mechanics and Foundations Division, A.S.C.E. 93(SM4):577-594.

Jacobs, D.G., J.S. Epler, and R.R. Rose. 1980. Identification of technical problems encountered in the shallow land burial of low-level radioactive wastes. ORNL/SUB-80/13619/1. Oak Ridge Natl. Lab., Oak Ridge, TN.

Khire, M.V., C.H. Benson, and P.J. Bosscher. 1999. Field data from a capillary barrier and model predictions with UNSAT-H. J. Geotechnical and Geoenvironmental Engineering. 125(6):518-527. 
Limbach, W.E., T.D. Ratzlaff, J.E. Anderson, T.D. Reynolds, and J.W. Laundre. 1994. Design and implementation of the protective cap/biobarrier experiment at the Idaho National Engineering Laboratory. P. 359-377. In Proc. Of the $33^{\text {rd }}$ Hanford Symposium on Health and the Environment. 7-11 Nov. 1994. Richland, WA. Battelle Press. Columbus, OH.

Magnuson, S. O. 1993. A simulation study of moisture movement in proposed barriers for the Subsurface Disposal Area, INEL, EGG-WM-10974, EG\&G Idaho, Inc., Idaho Falls, ID.

Melchior, S., K. Berger, B. Vielhaber, and G. Miehlich. 1994. Multilayered landfill covers: Field data on the water balance and liner performance. p. 411-425. In Proc. Of the $33^{\text {rd }}$ Hanford Symposium on Health and the Environment. 7-11 Nov. 1994. Richland, WA. Battelle Press. Columbus, OH.

Miller, D.E. and W.C. Bunger. 1963. Moisture retention by soil with coarse layers in the profile. Soil Sci. Soc. Am. Proc. 27:586-589.

Mitchell, J.K. 1976. Fundamentals of soil behavior. John Wiley \& Sons, Inc. New York.

Nativ, R. 1991. Radioactive waste isolation in arid zones. J. Arid Environ. 20:129-140.

Nelson, W.R. and L.D. Baver. 1941. Movement of water through soils in relation to the nature of the pores. Soil Sci. Soc. Am. Proc. 5:69-76.

Nyhan, J.W., T.E. Hakonson, and B.J. Drennon. 1990. A water balance study of two landfill cover designs for semiarid regions. J. Environ. Qual. 19:281-288.

O’Donnell, E., R.W. Ridky, and R.K. Schulz. 1994. Control of water infiltration into near-surface, lowlevel waste-disposal units in humid regions. p. 295-324. In Proc. Of the $33^{\text {rd }}$ Hanford Symposium on Health and the Environment. 7-11 Nov. 1994. Richland, WA. Battelle Press. Columbus, OH.

Omidi, G.H., J.C. Thomas, and K.W. Brown. 1996. Effect of desiccation cracking on the hydraulic conductivity of a compacted clay liner. Water Air Soil Pollut. 89:91-103.

Petersen, K.L., S.O. Link, and G.W. Gee. 1995. Hanford site long-term surface barrier development program: Fiscal year 1994 highlights. PNL-10605. Pacific Northwest Lab., Richland, WA.

Robins, J.S. 1959. Moisture movement and profile characteristics in relation to field capacity. Intern. Comm. on Irrigation and Drainage: 8.509-8.521.

Rodriguez, A.R., H. del Castillo, and G.F. Sowers. 1988. Soil mechanics in highway engineering. Trans Tech Publications, Clausthal-Zellerfeld, Germany.

Skahn, K. 1997. EPA's performance, monitoring, and maintenance requirements for landfill caps. P. 1925. In T.D. Reynolds and R.C. Morris (ed.) Landfill capping in the semi-arid west: Problems, perspectives, and solutions Conf. Proc., Grand Teton National Park, WY. 21-22 May, 1997. Environ. Sci. and Res. Foundation, Idaho Falls, ID.

Stormont, J.C. and C.E. Anderson. 1999. Capillary barrier effect from underlying coarser soil layer. J. Geotechnical and Geoenvironmental Engineering. 125(8):641-648.

Suter, G.W., R.J. Luxmoore, and E.D. Smith. 1993. Compacted soil barriers at abandoned landfill sites are likely to fail in the long term. J. Environ. Qual. 22(2):217-226. 
U.S. Environmental Protection Agency. 1989. Technical guidance document: Final covers on hazardous waste landfills and surface impoundments. USEPA Rep. 530-SW-89-047. Office of Solid Waste and Emergency Response, USEPA, Washington, DC.

Ward, A.L. and G.W. Gee. 1997. Performance evaluation of a field-scale surface barrier. J. Environ. Qual. 26:694-705.

Warren, R.W., T.E. Hakonson, and K.V. Bostick. 1997. The hydrologic evaluation of four cover designs for hazardous waste landfills. p. 181-197. In T.D. Reynolds and R.C. Morris (ed.) Landfill capping in the semi-arid west: Problems, perspectives, and solutions Conf. Proc., Grand Teton National Park, WY. 21-22 May, 1997. Environ. Sci. and Res. Foundation, Idaho Falls, ID. 